\title{
活性炭催化苯一步羟基化制备苯酚
}

\author{
徐加泉, 刘慧慧, 杨瑞光, 李桂英 ${ }^{\mathrm{a}}$, 胡常伟 ${ }^{\mathrm{b}}$ \\ 四川大学化学学院绿色化学与技术教育部重点实验室, 四川成都 610064
}

\begin{abstract}
摘要: 将市售活性炭经过硝酸、过氧化氢及不同温度进行处理后用于苯的羟基化反应, 并研究了活性炭催化苯着基化反应机理. 用 Boehm 滴定, $\mathrm{N}_{2}$ 吸附-脱附及 $\mathrm{X}$ 射线光电子能谱对活性炭进行了表征. 结果表明, 反应体系的 $\mathrm{pH}$ 对催化剂活性具有重要的 影响, 活性炭对苯的吸附受表面含氧基团含量的影响. 模型化合物反应结果表明, 活性炭表面的酚羟基和羰基是反应的活性位, 两者可相互转化, 并在一定的 $\mathrm{pH}$ 条件下达到平衡, 该转化使得 $\mathrm{H}_{2} \mathrm{O}_{2}$ 活化为羟基自由基, 进而与苯反应生成苯酚. 在苯羟基化 反应中, 活性炭表现出良好且稳定的催化性能, 苯酚收率可达 $14.4 \%$.
\end{abstract}

关键词：活性炭；苯；羟基化；含氧基团；模型化合物；苯酚

中图分类号: O643 文献标识码: A

收稿日期: 2012-05-10. 接受日期: 2012-06-13.

a通讯联系人. 电话/传真: (028)85415745; 电子信箱：gchem@scu.edu.cn

通讯联系人。电话/传真: (028)85411105; 电子信箱: chwehu@mail.sc.cninfo.net

基金来源: 国家自然科学基金 (20502017, 20872102).

本文的英文电子版(国际版)由Elsevier出版社在ScienceDirect上出版(http://www.sciencedirect.com/science/journal/18722067).

\section{Hydroxylation of Benzene by Activated Carbon Catalyst}

\author{
XU Jiaquan, LIU Huihui, YANG Ruiguang, LI Guiying ${ }^{\text {a }}$, HU Changwei ${ }^{\mathrm{b}}$ \\ Key Laboratory of Green Chemistry and Technology, Ministry of Education, College of Chemistry, Sichuan University, \\ Chengdu 610064, Sichuan, China
}

\begin{abstract}
Phenol is widely used in industry. The hydroxylation of benzene to phenol can meet the increasing requirement for phenol and green chemistry. Commercial wood-based activated carbon was treated by different methods, including oxidation by nitric acid and hydrogen peroxide and thermal treatment at different temperatures, and used as the catalyst for the hydroxylation of benzene to phenol in acetonitrile using $\mathrm{H}_{2} \mathrm{O}_{2}$ as oxidant. The mechanism of the hydroxylation was also investigated. The activated carbon samples were characterized by Boehm titration, nitrogen adsorption, and X-ray photoelectron spectroscopy. The $\mathrm{pH}$ had a significant effect on the phenol yield. The effect of benzene adsorption was also investigated. Several model compounds with oxygen groups were used as catalysts for the hydroxylation of benzene. The reaction between phenolic hydroxyl and quinone on the surface of activated carbon was responsible for the hydroxylation of benzene to phenol when it activated $\mathrm{H}_{2} \mathrm{O}_{2}$ to form the hydroxyl radical. Activated carbon was an efficient and stable catalyst and a maximum phenol yield of $14.4 \%$ was obtained under the optimal reaction conditions.
\end{abstract}

Key words: activated carbon; benzene hydroxylation; oxygen group; model compound; mechanism

Received 10 May 2012. Accepted 13 June 2012.

${ }^{a}$ Corresponding author.Tel/Fax: +86-28-85415745; E-mail: gchem@scu.edu.cn

${ }^{b}$ Corresponding author.Tel/Fax: +86-28-85411105; E-mail: chwehu@mail.sc.cninfo.net

This work was supported by the National Natural Science Foundation of China (20502017, 20872102).

English edition available online at Elsevier ScienceDirect (http://www.sciencedirect.com/science/journal/18722067).

Phenol is an intermediate for preparing chemicals such as phenol resins, fibers, caprolactam, adipic acid, dyestuffs, and medicine. More than $90 \%$ of the phenol produced in industry is based on the cumene route, which produces ace- tone as a byproduct [1]. The direct hydroxylation of benzene to phenol with a clean oxidant is an alternative route to the cumene process. Oxidants employed in the hydroxylation of benzene are hydrogen peroxide, molecular oxygen, 
and $\mathrm{N}_{2} \mathrm{O}$. Using nitrous oxide as oxidant can give a high phenol yield and selectivity [2,3] but the process has an economic advantage only when nitrous oxide is a byproduct from adipic acid production. When molecular oxygen is used as an economic and clean oxidant, there is only low activity, even in complex systems [1,4-6]. For the hydroxylation of benzene with $\mathrm{H}_{2} \mathrm{O}_{2}$ as oxidant, many catalysts have been used, such as TS-PQ ${ }^{\mathrm{TM}}$ [7], NaY zeolite [8], heteropoly acid [9], Fe/MWCNTS [10], $\mathrm{VO}_{2}$-defects/ MWCNT [11], Fe/activated carbon [12,13], and activated carbon [14], where the oxygen groups on the surface was reported to have an effect on the activity.

Activated carbon is an important catalyst and catalyst support because of its physical properties and surface functional groups $[15,16]$. With a metal/activated carbon catalyst, the metal species is usually the active phase for the hydroxylation of benzene, while the activated carbon is just a support [12,13]. Activated carbon has good catalytic activity in oxidation reactions because of its ability to accept electrons. Carbonyl/quinone groups play an important role in the oxidation reaction [17-19]. Hydroxyl radicals can be produced by the activation of hydrogen peroxide on activated carbon [20,21], and the hydroxyl radicals were stabilized by resonance on the carbon surface [22-24].

Separation in a homogeneous catalytic system and leaching of active components from supported catalysts are still challenges for the hydroxylation of benzene using $\mathrm{H}_{2} \mathrm{O}_{2}$ as the oxidant [25]. In the present work, a cheap and easily prepared catalyst was obtained by the modification of wood-based activated carbon. The role of surface oxygen groups on the activated carbon and effect of $\mathrm{pH}$ on the yield of phenol were investigated.

\section{Experimental}

\subsection{Catalyst preparation}

Commercially available wood-based activated carbon from Jiangsu Nantong Activated Carbon Cooperation (China) with a particle size of $0.42-0.85 \mathrm{~mm}$ was washed by distilled water and then dried at $110{ }^{\circ} \mathrm{C}$ to obtain the sample named WAC. WAC (1.0 g) was immersed in a series of nitric acid solutions $(10.0 \mathrm{ml})$ of different concentrations at room temperature for $24 \mathrm{~h}$, and then washed by boiled distilled water until it reached a constant $\mathrm{pH}$ and finally dried at $110^{\circ} \mathrm{C}$ for $12 \mathrm{~h}$. The samples were denoted as WAC $-x \mathrm{~N}$ ( $x$ was the concentration of nitric acid solution, $\mathrm{mol} / \mathrm{L})$.

The sample WAC- $0.5 \mathrm{~N}$ was placed in a quartz tube in $\mathrm{N}_{2}$ flow $\left(50.0 \mathrm{~cm}^{3} / \mathrm{min}\right)$ and heated at $10.0{ }^{\circ} \mathrm{C} / \mathrm{min}$ from room temperature to the desired temperature which was held for 4 h. After that, the system was cooled down to room tem- perature in $\mathrm{N}_{2}$ flow $\left(50 \mathrm{~cm}^{3} / \mathrm{min}\right)$. The samples were labeled as WAC- $0.5 \mathrm{~N}-y$ ( $y$ was the temperature of thermal treatment, ${ }^{\circ} \mathrm{C}$ ). Part of WAC-0.5N was treated further with $30 \%$ $\mathrm{H}_{2} \mathrm{O}_{2}\left(1.0 \mathrm{~g}\right.$ WAC-0.5N with 4.0 , 8.0, or $12.0 \mathrm{ml} \mathrm{H}_{2} \mathrm{O}_{2}$ ) at $70{ }^{\circ} \mathrm{C}$ for $6 \mathrm{~h}$. The samples were named WAC- $0.5 \mathrm{~N}-z \mathrm{H}(z$ was the ratio between the volume of $30 \% \mathrm{H}_{2} \mathrm{O}_{2}$ solution and the amount of WAC- $0.5 \mathrm{~N}$ sample, $\mathrm{ml} / \mathrm{g}$ ).

\subsection{Catalyst characterization}

Titration of the samples was carried out using the Boehm method [26-29]. Aqueous solutions of $\mathrm{NaHCO}_{3}, \mathrm{NaOH}$, and $\mathrm{Na}_{2} \mathrm{CO}_{3}$ with a concentration of $0.05 \mathrm{~mol} / \mathrm{L}$ were used in the titration. $0.05 \mathrm{~mol} / \mathrm{L}$ of $\mathrm{CH}_{3} \mathrm{CH}_{2} \mathrm{ONa}$ was freshly prepared using chromatography pure ethanol and sodium. Each sample $(0.50 \mathrm{~g})$ was placed in $50 \mathrm{ml}$ of the above alkaline solutions for $24 \mathrm{~h}$ at room temperature. Excess hydrochloric acid solution $(0.10 \mathrm{~mol} / \mathrm{L})$ was added to the filtrate, and this was then back titrated with $\mathrm{NaOH}$ using methyl red as indicator.

In situ infrared (IR) spectroscopy was used to monitor the oxidation of hydroquinone by $\mathrm{H}_{2} \mathrm{O}_{2}$ in acetonitrile at different pHs at $70{ }^{\circ} \mathrm{C}$. In situ IR was carried out on a ReactIR ic10 (Mettler Toledo). The absorption intensity of hydroquinone and quinone in the reaction was detected using their characteristic absorption at 1517 and $1661 \mathrm{~cm}^{-1}$, respectively.

The BET surface area $\left(A_{\mathrm{BET}}\right)$ of the samples was measured by $\mathrm{N}_{2}$ adsorption at $-196{ }^{\circ} \mathrm{C}$ on a Micromeritics Instrument (Tri-star II). Prior to measurement, the sample was evacuated at $100{ }^{\circ} \mathrm{C}$ to a pressure of less than $10^{-2} \mathrm{~Pa}$. The BET equation was used to get the surface area from the $\mathrm{N}_{2}$ adsorption isotherm. The micropore volume $\left(V_{\text {mic }}\right)$, micropores surface area $\left(A_{\text {mic }}\right)$, and external surface area $\left(A_{\text {ext }}\right)$ were obtained using the $t$-plot method.

To determine the surface oxygen groups and corresponding carbon species on the activated carbon, X-ray photoelectron spectroscopy (XPS) characterization was carried out on an XSAM800 spectrometer (KRATOS) using Al $K_{\alpha}$ radiation $(1486.6 \mathrm{eV})$. The source was operated at $12 \mathrm{kV}$ and $12 \mathrm{~mA}$. The binding energy was calibrated with $\mathrm{C} 1 \mathrm{~s}$ at $284.8 \mathrm{eV}$. A linear background was subtracted from all spectra and then peak fitting was performed with a $80 / 20$ Lorentz-Gauss function.

\subsection{Activity test}

To estimate the adsorption capacity of benzene, $0.5 \mathrm{~g}$ sample was added to a solution of $15.0 \mathrm{ml}$ acetonitrile, 6.0 $\mathrm{ml} \mathrm{H}_{2} \mathrm{O}$, and $0.5 \mathrm{ml}$ benzene. Adsorption was performed at $30{ }^{\circ} \mathrm{C}$ for $48 \mathrm{~h}$. The amount of benzene adsorbed on the activated carbon sample was calculated as $q=[21.5 \times$ 
$\left.\left(C_{0}-C_{1}\right)\right] / m$, where $q$ is the amount of benzene adsorbed, $C_{0}$ is the initial concentration of benzene in the solution, $C_{1}$ is the benzene concentration after $48 \mathrm{~h}$, and $m$ is the amount of sample used.

The hydroxylation of benzene was carried out in a two-necked $50 \mathrm{ml}$ round flask placed in a water bath. Typical reaction conditions were $0.60 \mathrm{~g}$ catalyst, $2.0 \mathrm{ml}(22.5$ mmol) benzene, $15.0 \mathrm{ml}$ acetonitrile, and $6.0 \mathrm{ml}(58.8$ mmol) hydrogen peroxide $\left(30 \mathrm{wt} \%\right.$ ) kept at $70{ }^{\circ} \mathrm{C}$ for $6 \mathrm{~h}$. The reaction mixture was filtered and analyzed by high performance liquid chromatography (Waters 1525P) using a reverse phase $\mathrm{C} 18$ column and an ultraviolet detector set at 225 and $254 \mathrm{~nm}$. The main products and byproducts were quantified using $o$-cresol as internal standard. $50 \mathrm{vol} \%$ water and $50 \mathrm{vol} \%$ acetonitrile were used as the mobile phase. All products were first identified by coupled gas chromatography and mass spectroscopy (Agilent 5973 Network $6890 \mathrm{~N})$. The amount of dihydroxy-benzene formed was small and no tar was detected in the crude reaction mixture. The yield of phenol was calculated as ( $\mathrm{mmol}$ phenol)/(mmol initial benzene). The selectivity for phenol was calculated as (mmol phenol)/(mmol phenol $+\mathrm{mmol}$ benzoquinone).

\section{Results and discussion}

\subsection{Textural characteristics of the samples}

The nitrogen adsorption isotherms and pore size distribution of different activated carbon samples are shown in Fig. 1. All the isotherms were type I [30], which meant that all the samples were microporous materials. The pore size distribution showed that the activated carbon samples were microporous materials. The appearance of hysteresis loops in the nitrogen isotherms indicated the existence of some mesoporosity. The hysteresis loops were type H4 with parallel adsorption and desorption branches, which suggested slit-shaped pores.

The details of the texture of the samples are shown in Table 1 . The results showed that the oxidation of the activated carbon sample with dilute nitric acid $(0.50 \mathrm{~mol} / \mathrm{L})$ increased $A_{\text {BET }}$ and $A_{\text {mic }}$, which was probably because this treatment made more pore openings [12], that is, ashes and other impurities in the pore channels were removed by the nitric acid. The anchoring of oxygen groups on the inner surface of the pores would also contribute to the increase of the micropores. However, as the concentration of nitric acid was increased, $A_{\mathrm{BET}}$ decreased because some macropores collapsed or because there were more oxygen groups extending from the wall of the slit-shaped mesopores [14,31].

$A_{\mathrm{BET}}$ and $A_{\text {Ext }}$ increased while $A_{\text {mic }}$ decreased when WAC- $0.5 \mathrm{~N}$ was further treated with $30 \% \mathrm{H}_{2} \mathrm{O}_{2}$, which was consistent with the results reported in the literature [32].
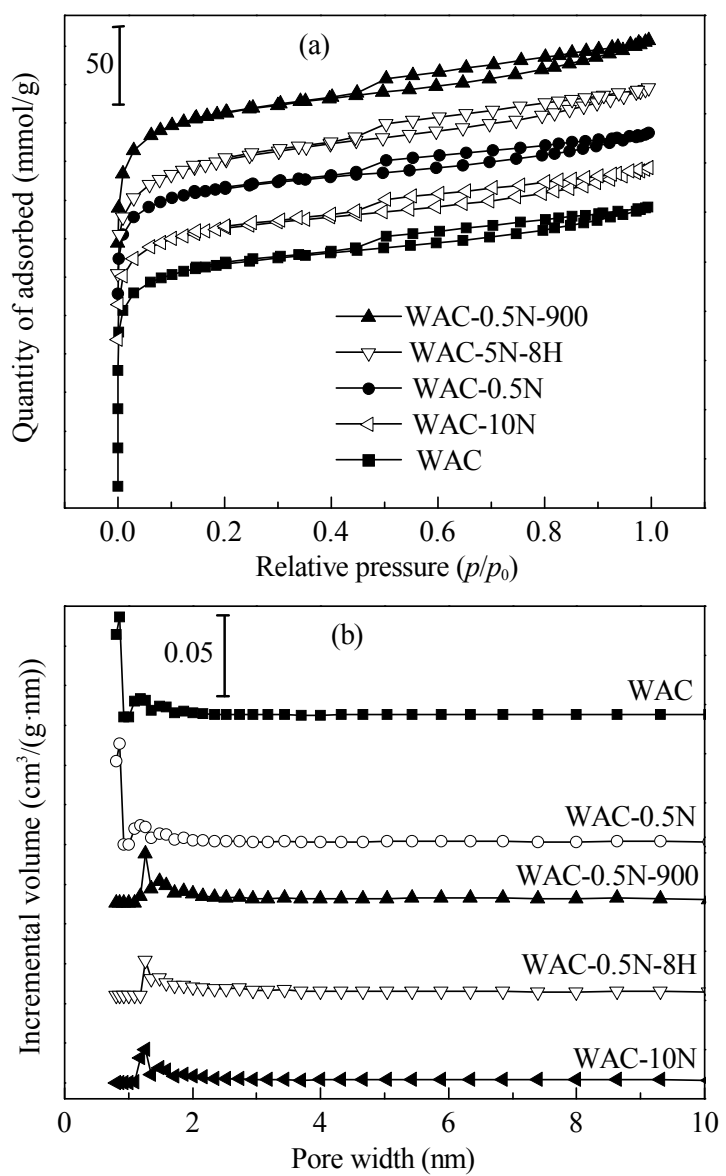

Fig. 1. $\mathrm{N}_{2}$ adsorption-desorption isotherms and pore size distribution of different activated carbon samples.

When the oxidized sample was treated at different temperatures, the surface area was increased and it reached a maximum with $650{ }^{\circ} \mathrm{C}$. A slight decomposition of the sample during the treatment resulting in the removal of oxygen groups as $\mathrm{CO}_{2}$ can explain this [33].

Table 1 Textural characteristic of the activated carbon samples

\begin{tabular}{lcccc}
\hline Sample & $V_{\text {mic }} /\left(\mathrm{m}^{3} / \mathrm{g}\right)$ & $A_{\mathrm{BET}} /\left(\mathrm{m}^{2} / \mathrm{g}\right)$ & $A_{\text {mic }} /\left(\mathrm{m}^{2} / \mathrm{g}\right)$ & $A_{\text {Ext }} /\left(\mathrm{m}^{2} / \mathrm{g}\right)$ \\
\hline WAC & 0.196 & 570 & 423 & 147 \\
WAC-0.5N & 0.212 & 603 & 460 & 143 \\
WAC-10N & 0.199 & 582 & 429 & 152 \\
WAC-0.5N-4H & 0.179 & 627 & 389 & 238 \\
WAC-0.5N-8H & 0.183 & 601 & 397 & 204 \\
WAC-0.5N-12H & 0.158 & 619 & 342 & 276 \\
WAC-0.5N-250 & 0.235 & 682 & 508 & 174 \\
WAC-0.5N-450 & 0.237 & 688 & 511 & 176 \\
WAC-0.5N-650 & 0.261 & 762 & 563 & 199 \\
WAC-0.5N-900 & 0.238 & 699 & 513 & 186 \\
\hline
\end{tabular}

\subsection{Boehm titration of the samples}

Table 2 summarizes the results of the Boehm titration of the samples. For the fresh samples, with the increase of the 
Table 2 Results of Boehm titration of the fresh and used activated carbon samples

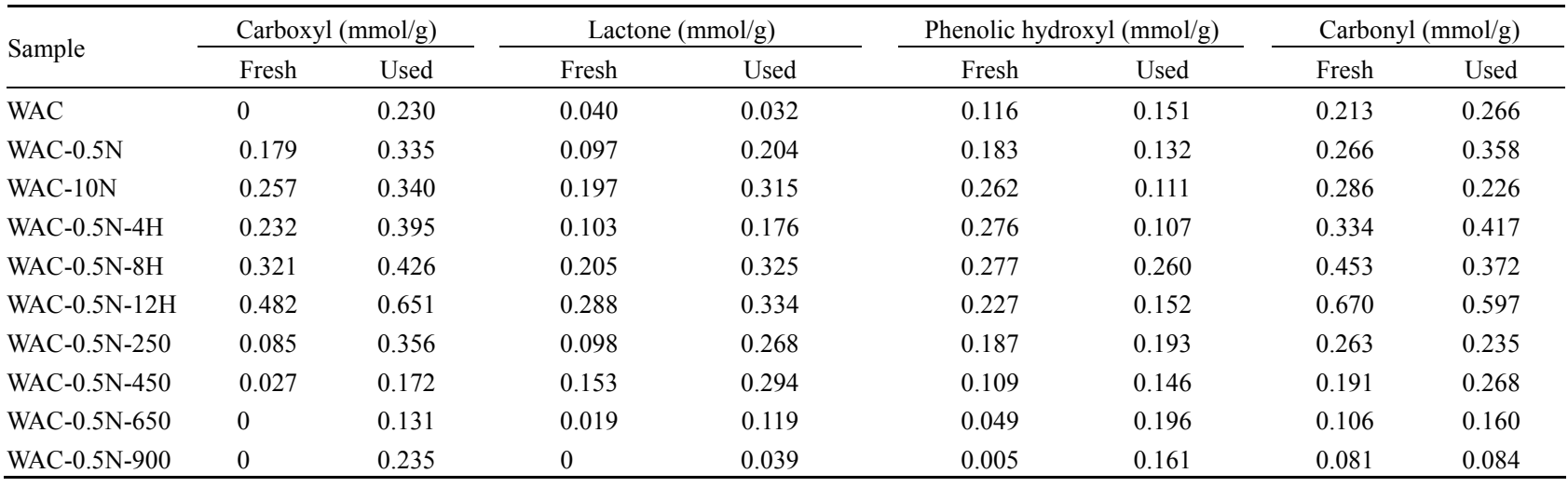

nitric acid concentration in the treatment, the amount of oxygen groups on the sample increased, which was in agreement with previous reports [15,34,35]. Plentiful oxygen groups were created on the surface of WAC- $0.5 \mathrm{~N}$ after it was treated with $\mathrm{H}_{2} \mathrm{O}_{2}$. For WAC-0.5N-4H, WAC- $0.5 \mathrm{~N}-8 \mathrm{H}$, and WAC- $0.5 \mathrm{~N}-12 \mathrm{H}$, with increasing amounts of $\mathrm{H}_{2} \mathrm{O}_{2}$ used, the amount of carboxyl, lactone, and carbonyl groups increased. When the oxidized sample was treated at $250{ }^{\circ} \mathrm{C}$, the amount of carboxyl groups decreased while the amounts of other oxygen groups did not change, which was in agreement with previous reports [34,36]. When the oxidized sample was heated at $450{ }^{\circ} \mathrm{C}$, the amount of carboxyl and phenolic hydroxyl groups decreased while the amount of lactone increased, which indicated that dehydration to form lactone occurred during the thermal treatment [37]. Carboxyl groups on the surface of WAC-0.5N were removed when the sample was treated at $650{ }^{\circ} \mathrm{C}$. After being treated at $900{ }^{\circ} \mathrm{C}$ for $4 \mathrm{~h}$, carboxyl groups and lactone on the surface of WAC- $0.5 \mathrm{~N}$ disappeared, while phenolic hydroxyl also nearly disappeared. The results were consistent with those in the literature [36].

The surface chemistry of the activated carbon after being used in the hydroxylation reaction was also investigated (Table 2). The amounts of carboxyl groups and lactone had increased distinctly during the reaction, except with WAC on which the amount of lactone had decreased slightly. For the samples treated above $450{ }^{\circ} \mathrm{C}$, the amount of both phenolic hydroxyl and carbonyl groups were increased, while for the other samples, the phenolic and carbonyl groups were changed. It was reported that the surface chemistry of multi-walled carbon nanotubes can be changed by an oxidation reaction [10]. The surface chemistry of the samples in this work was easily changed by the oxidation reaction. The changes were larger for samples with a lower amount of oxygen groups before it was used in the reaction.

\subsection{Activity of the catalysts}

The catalytic activity in terms of phenol yield (average value from at least three measurements) is shown in Table 3. The differences in activity of the activated carbon catalysts were small for the majority of the samples. The unmodified WAC sample showed low activity for the hydroxylation of benzene. The activity of sample WAC- $0.5 \mathrm{~N}$ which was treated with nitric acid was increased to a high level. However, the activity of the activated carbon samples did not increase with the increase of nitric acid concentration. The yield of phenol from WAC-10N (11.5\%) was slightly lower than that from WAC- $0.5 \mathrm{~N}(12.5 \%)$. After being treated further with $\mathrm{H}_{2} \mathrm{O}_{2}$, the samples became more active and the highest phenol yield of $13.5 \%$ was obtained with WAC $-0.5 \mathrm{~N}-8 \mathrm{H}$ and WAC- $0.5 \mathrm{~N}-12 \mathrm{H}$. The heat treatment of WAC- $0.5 \mathrm{~N}$ at $900{ }^{\circ} \mathrm{C}$ for $4 \mathrm{~h}$ resulted in a drastic decrease in the yield of phenol from $12.5 \%$ to $7.6 \%$. This showed that the hydroxylation activity was related to the surface oxygen groups of the sample.

Table 3 Yield of phenol over the catalysts

\begin{tabular}{lcc}
\hline Sample & Yield of phenol (\%) & Selectivity for phenol (\%) \\
\hline WAC & 1.3 & 99.7 \\
WAC-0.5N & 12.5 & 86.3 \\
WAC-10N & 11.5 & 89.2 \\
WAC-0.5N-4H & 12.7 & 86.9 \\
WAC-0.5N-8H & 13.5 & 86.3 \\
WAC-0.5N-12H & 13.5 & 84.8 \\
WAC-0.5N-250 & 12.0 & 86.6 \\
WAC-0.5N-450 & 12.1 & 86.6 \\
WAC-0.5N-650 & 11.1 & 86.9 \\
WAC-0.5N-900 & 7.6 & 89.0 \\
\hline
\end{tabular}

\subsection{Effect of $\mathrm{H}^{+}$on the reaction}

It was reported that the rate of hydrogen peroxide decomposition into hydroxyl radicals was dependent on the aqueous phase $\mathrm{pH}$ [38] when the reaction was catalyzed by activated carbon, while the oxidation reactions were also affected by $\mathrm{pH}$ [39]. In order to investigate the effect of the aqueous phase $\mathrm{pH}$ on the activities of the samples, the hydroxylation of benzene over WAC-0.5N-650 was performed 
with various aqueous phase $\mathrm{pH}$ values, which were adjusted by using solutions of perchloric acid and sodium hydroxide. Figure 2 shows that the concentration of $\mathrm{H}^{+}\left(\left[\mathrm{H}^{+}\right]\right)$had a significant effect on the yield of phenol. The phenol yield increased with $\left[\mathrm{H}^{+}\right]$from $2.63 \mathrm{~mol} / \mathrm{L}$ to $0.22 \mathrm{~mol} / \mathrm{L}(\mathrm{pH}=$ $0.66)$, and then decreased when $\left[\mathrm{H}^{+}\right]$was decreased from $0.22 \mathrm{~mol} / \mathrm{L}(\mathrm{pH}=0.66)$ to $3.31 \times 10^{-7} \mathrm{~mol} / \mathrm{L}(\mathrm{pH}=6.48)$. A blank experiment was carried out by using $\left[\mathrm{H}^{+}\right]=0.22$ $\mathrm{mol} / \mathrm{L}(\mathrm{pH}=0.66)$ in the absence of a catalyst and only a trace amount of phenol $(0.3 \%)$ was detected. Another control experiment was also carried out employing WAC- $0.5 \mathrm{~N}-\mathrm{NaOH}$, which was WAC- $0.5 \mathrm{~N}$ treated with $\mathrm{NaOH}$, as catalyst and only $1.1 \%$ phenol yield was obtained. The results indicated that both $\mathrm{H}^{+}$and the catalyst were necessary to the reaction.

XPS was employed to characterize the surface chemistry of sample WAC- $0.5 \mathrm{~N}-650$ after reaction with different $\left[\mathrm{H}^{+}\right]$. The results are shown in Fig. 3 and Table 4. By reference to the literature [40], for surface oxygen, the deconvoluted peaks at the binding energies of 530.3-531.8, 531.9-533.4,

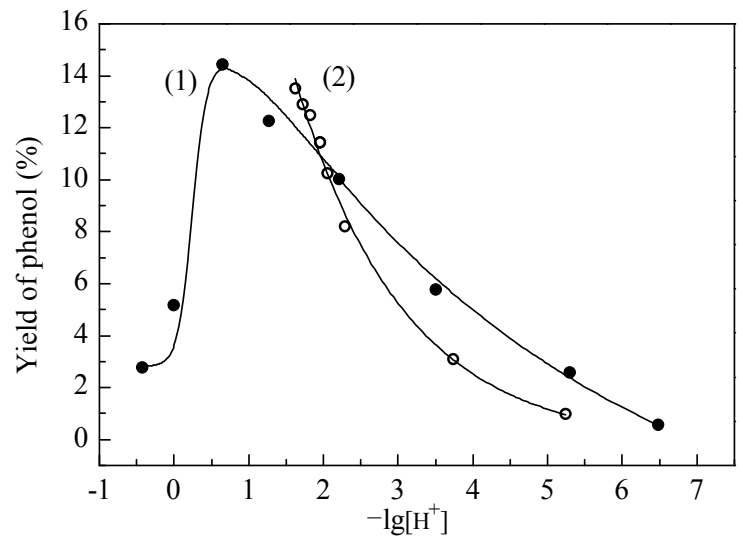

Fig. 2. Relationship between $\left[\mathrm{H}^{+}\right]$in the reaction system and the phenol yield over WAC-0.5N-650 (1) and other samples used in our work (2).
Table 4 Deconvolution of O $1 s$ XPS spectra for WAC-0.5N-650 after reaction with different $\left[\mathrm{H}^{+}\right]$

\begin{tabular}{lcccc}
\hline & \multicolumn{4}{c}{ Surface oxygen (\%) } \\
\cline { 2 - 5 }$\left[\mathrm{H}^{+}\right] /(\mathrm{mol} / \mathrm{L})$ & Carbonyl & $\begin{array}{c}\text { Alcohol } \\
\text { /ether }\end{array}$ & $\begin{array}{c}\text { Carboxyl } \\
\text { /ester }\end{array}$ & Chemisorbed \\
\hline $0.22(\mathrm{pH} 0.66)$ & 31.18 & 31.58 & 15.59 & 21.65 \\
$0.01(\mathrm{pH} 1.95)$ & 29.92 & 32.64 & 16.44 & 21.00 \\
$3.2 \times 10^{-4}(\mathrm{pH} \mathrm{3.49)}$ & 28.97 & 32.73 & 15.74 & 22.55 \\
\hline
\end{tabular}

533.4-533.6, and 534.8-535.6 eV corresponded to carbonyl groups, alcohol and/or ether groups, carboxyl and/or ester groups, and chemisorbed oxygen and/or water, respectively. As shown in Fig. 3 and Table 4, the relative amounts of the four kinds of oxygen groups on WAC- $0.5 \mathrm{~N}-650$ after reaction at different $\left[\mathrm{H}^{+}\right]$were almost the same, indicating that the samples kept under different $\left[\mathrm{H}^{+}\right]$had almost the same surface chemistry. Therefore the difference in phenol yield shown in Fig. 2(1) was mainly caused by the variation of $\left[\mathrm{H}^{+}\right]$. The surface chemistry during the reaction under different $\left[\mathrm{H}^{+}\right]$was similar.

The results shown in the Fig. 4 indicated that the $\mathrm{pH}$ of the reaction solution decreased with increasing amount of oxygen groups on the activated carbon samples. The relationship between phenol yield over different catalysts and $\left[\mathrm{H}^{+}\right]$of the reaction system is shown in Fig. 2(2), where the variation of $\left[\mathrm{H}^{+}\right]$of the system was caused by the structure of the catalyst. As shown in Fig. 2, Fig. 2(2) was not the same as Fig. 2(1), which confirmed that the structure of the activated carbon also affected the activity of the catalyst besides the $\mathrm{pH}$. It can be seen that the oxygen groups on the activated carbon contributed to the activity by both affecting the $\mathrm{pH}$ of the system and by structural effects. Chen et al. [14] had reported that the carboxyl had a large effect on the phenol yield, which may be caused by the change of $\left[\mathrm{H}^{+}\right]$in the system.

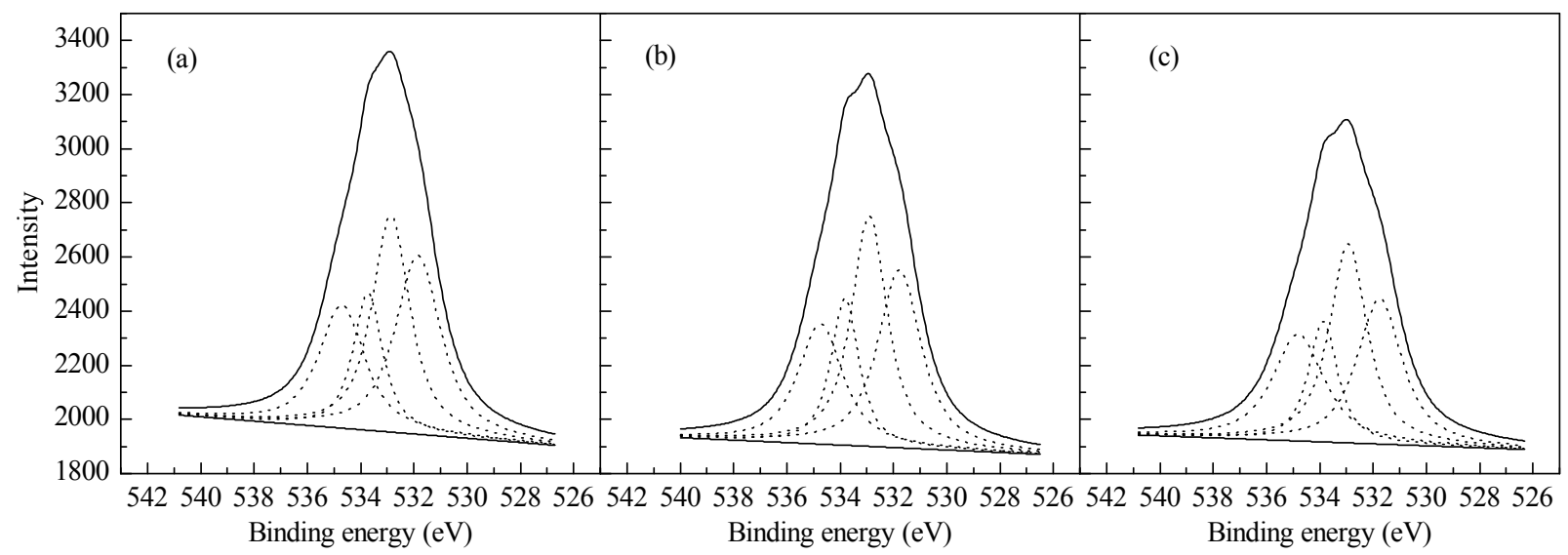

Fig. 3. O $1 s$ XPS spectra of sample WAC-0.5N-650 after reaction with different $\left[\mathrm{H}^{+}\right]$. (a) $\left[\mathrm{H}^{+}\right]=0.22 \mathrm{~mol} / \mathrm{L}(\mathrm{pH}=0.66) ;\left(\right.$ b) $\left[\mathrm{H}^{+}\right]=0.01 \mathrm{~mol} / \mathrm{L}(\mathrm{pH}$ $=1.95) ;(\mathrm{c})\left[\mathrm{H}^{+}\right]=3.2 \times 10^{-4} \mathrm{~mol} / \mathrm{L}(\mathrm{pH}=3.49)$. 


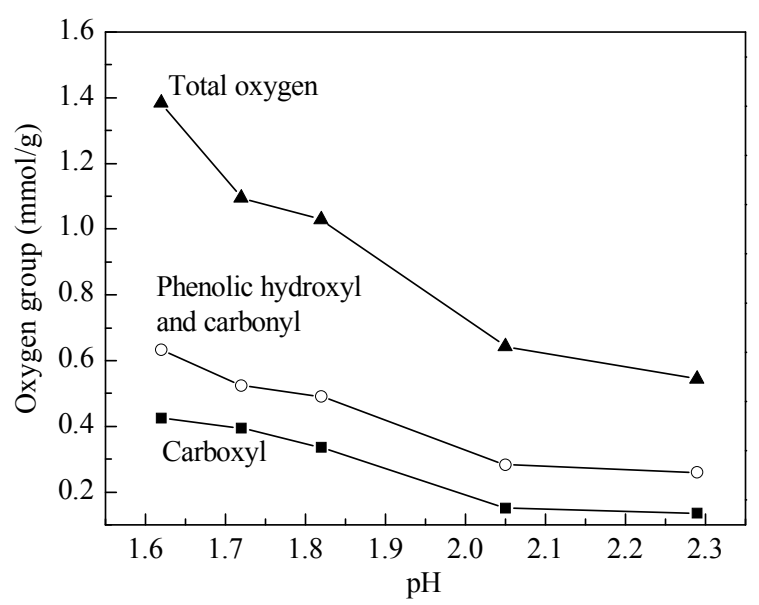

Fig. 4. Relationship between $\mathrm{pH}$ and amount of oxygen groups on the activated carbon after reaction.

\subsection{Catalytic performance with model compounds}

In order to identify the roles of the oxygen-containing species, homogeneous reactions were performed under the same reaction conditions using model compounds containing carboxyl, quinone, or hydroquinone groups. The structural environment of these groups in the model compounds was similar to that of these groups on activated carbon [17]. As shown in Table 5, 0.3\% phenol yield was obtained when the hydroxylation of benzene was carried out using $\mathrm{H}_{2} \mathrm{O}_{2}$ as oxidant in the absence of catalyst, and a similar phenol yield $(0.2 \%)$ was obtained when $\left[\mathrm{H}^{+}\right]$was adjusted to $0.14 \mathrm{~mol} / \mathrm{L}$ $(\mathrm{pH}=0.86)$. As compared with the reaction without a catalyst $(0.3 \%$ phenol yield), the reaction catalyzed by benzoic acid had a similar phenol yield $(0.4 \%)$. This indicated that the carboxylic acid groups on the activated carbon samples were not essential for the catalysis, and its function was to provide $\mathrm{H}^{+}$. On the other hand, a higher phenol yield was obtained using hydroquinone $(0.6 \%)$ and catechol $(0.7 \%)$ as homogeneous catalyst, implying that the carbonyl and hydroxyl groups on the surface of the activated carbon sam-

Table 5 Activity of model compounds as the catalyst in the hydroxylation of benzene

\begin{tabular}{lcc}
\hline Sample & {$\left[\mathrm{H}^{+}\right] /(\mathrm{mol} / \mathrm{L})$} & Yield of phenol $(\%)$ \\
\hline Quinone & $\mathrm{NA}$ & 0.3 \\
& $0.14(\mathrm{pH}=0.86)$ & 1.3 \\
Catechol & $\mathrm{NA}$ & 0.7 \\
& $0.14(\mathrm{pH}=0.86)$ & 2.8 \\
Hydroquinone & $\mathrm{NA}$ & 0.6 \\
& $0.14(\mathrm{pH}=0.86)$ & 2.7 \\
Benzoic acid & $\mathrm{NA}$ & 0.4 \\
& $0.14(\mathrm{pH}=0.86)$ & 0.4 \\
Blank & $\mathrm{NA}$ & 0.3 \\
& $0.14(\mathrm{pH}=0.86)$ & 0.2 \\
\hline
\end{tabular}

NA: $\left[\mathrm{H}^{+}\right]$of the system was not adjusted by acid or alkali. ples were the active species. The phenol yield increased remarkably when hydrochloric acid was used to adjust the $\mathrm{pH}$ of the reaction system to 0.86 with hydroquinone $(2.7 \%$ phenol yield), catechol (2.8\% phenol yield), and quinone (1.3\% phenol yield) as catalysts, which confirmed that $\mathrm{H}^{+}$ facilitated the reaction. Possibly the carbonyl pairs at the edge of the carbon layers behaved similarly to quinones, and the hydroxyl pairs acted similarly to hydroquinone [41], and this redox cycle was involved in the hydroxylation of benzene over the activated carbon catalyst.

To investigate the effect of $\left[\mathrm{H}^{+}\right]$on phenol yield, hydroquinone was used as the catalyst with various $\left[\mathrm{H}^{+}\right]$. The results are shown in Fig. 5. The highest phenol yield was obtained at a $\left[\mathrm{H}^{+}\right]$of $0.14 \mathrm{~mol} / \mathrm{L}(\mathrm{pH}=0.86)$.

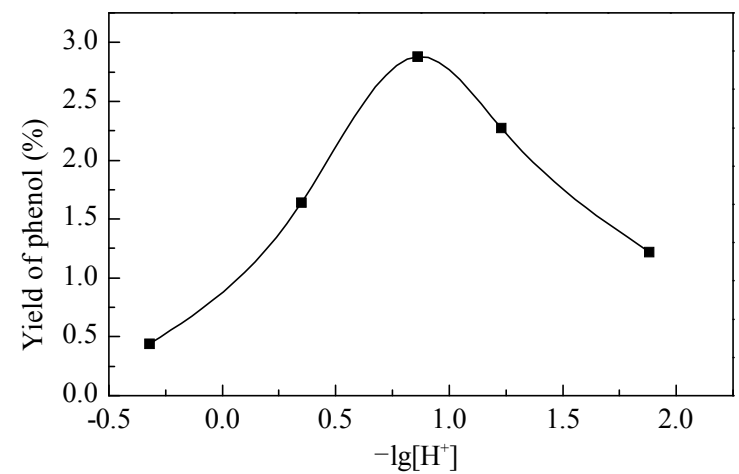

Fig. 5. Effect of $\mathrm{H}^{+}$on phenol yield using hydroquinone as catalyst.

To study how $\left[\mathrm{H}^{+}\right]$affected the reaction, in situ IR was used to monitor the oxidization of hydroquinone by $\mathrm{H}_{2} \mathrm{O}_{2}$. The result was shown in Fig. 6. When the reaction was carried out at a $\left[\mathrm{H}^{+}\right]$of $0.01 \mathrm{~mol} / \mathrm{L}(\mathrm{pH}=2.0)$, it was difficult for hydroquinone to be oxidized to quinone. When the reaction was carried at a $\left[\mathrm{H}^{+}\right]$of $2.75 \mathrm{~mol} / \mathrm{L}$, hydroquinone was oxidized to quinone quickly. When the reaction was carried at a $\left[\mathrm{H}^{+}\right]$of $0.14 \mathrm{~mol} / \mathrm{L}(\mathrm{pH}=0.86)$, hydroquinone was oxidized to quinone, and an equilibrium was established between the hydroquinone and quinone. Thus the equilibrium

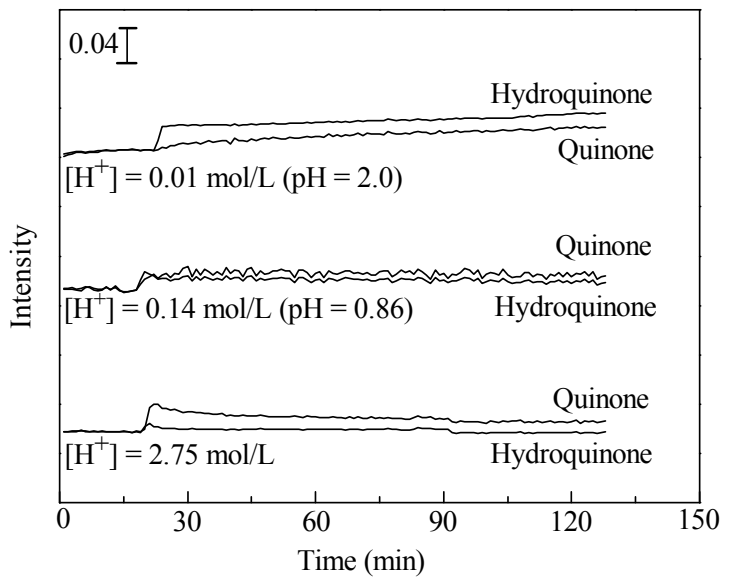

Fig. 6. IR spectra of hydroquinone for various $\left[\mathrm{H}^{+}\right]$. 
between hydroquinone and quinone plays an important role in the hydroxylation of benzene. The function of $\mathrm{H}^{+}$in this system may be similar to its role in the Fenton system. The transformation between phenolic hydroxyl and quinone is similar to the cycle between $\mathrm{Fe}^{2+}$ and $\mathrm{Fe}^{3+}$.

\subsection{Benzene adsorption}

The amount of benzene adsorbed on different catalysts was also investigated. A close relationship between the amount of benzene adsorbed and the amount of total oxygen groups on the activated carbon is shown in Fig. 7. The amount of benzene adsorbed decreased with increased total oxygen groups. The results showed that benzene adsorption was influenced by the surface chemistry of the catalyst, which was consistent with a previous report [42], where the amount of benzene adsorbed decreased with decreasing $\mathrm{pH}$ at the point of zero charge of activated carbon samples. It is known that the adsorption of the substrate has a significant effect on the heterogeneously catalyzed reaction. The activity of the catalyst usually decreases with decreased substrate adsorption. Thus, increased total oxygen would decrease the activity of catalyst by decreasing the amount of benzene adsorbed, which was in accord with the results obtained by Chen et al. [14].

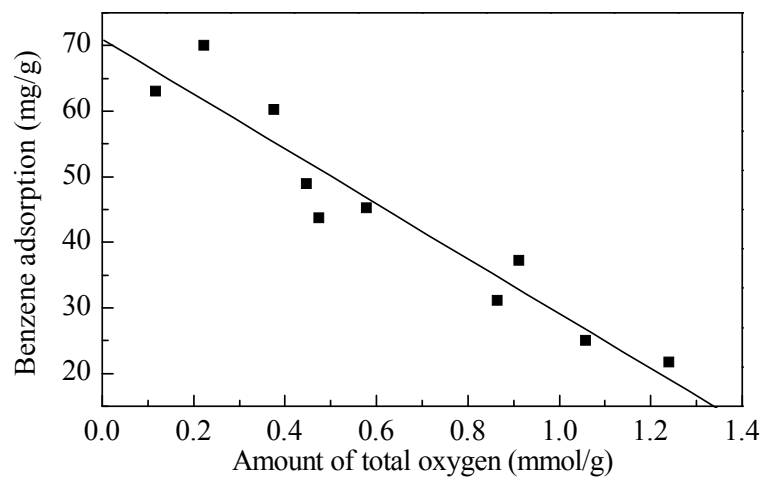

Fig. 7. Dependence of amount of benzene adsorbed on the amount of oxygen groups.

\subsection{Active site on the activated carbon catalyst}

Inductive coupled plasma analysis indicated that WAC possessed some $\mathrm{Na}^{+}, \mathrm{K}^{+}$, and other impurities. To probe if these impurities also affected the catalytic performance, a control experiment was carried out employing WAC- $-0.5 \mathrm{~N}-900$ as catalyst. When $2.0 \mathrm{mmol} \mathrm{NaCl}$ was added into the reaction system only $2.3 \%$ phenol yield was obtained. As compared to the result in Table 3, the phenol yield in the presence of $\mathrm{NaCl}$ was drastically decreased $(7.6 \%$ vs $2.3 \%)$. The results suggested that the presence of the salt in the reaction system affected the catalytic per- formance of that sample. Therefore, impurities from WAC dissolved in the system may also reduce the hydroxylation activity. Thus, in the following discussion about the effect of oxygen groups on the catalytic performance, WAC is not included because of its high impurity content.

To probe the relationship between the chemistry of the samples and catalytic performance, the amount of oxygen groups on activated carbon before and after reaction were measured. The results indicated that the oxygen groups were related to the catalytic activity. Figure 8 showed relationship between the sum of phenolic hydroxyl and carbonyl groups of the activated carbon samples after reaction and the phenol yield. The yield of phenol increased as the sum of phenolic hydroxyl and carbonyl increased, and then became constant. The dependence of phenol yield on the amount of other surface oxygen groups of the activated carbon before and after reaction was also studied, but the correlation was not as good. It was deduced that the phenolic hydroxyl and carbonyl groups on the activated carbon samples were the active sites for the hydroxylation of benzene. In the literature [19], these phenolic hydroxyl and carbonyl groups were shown to be active for related oxidation reactions.

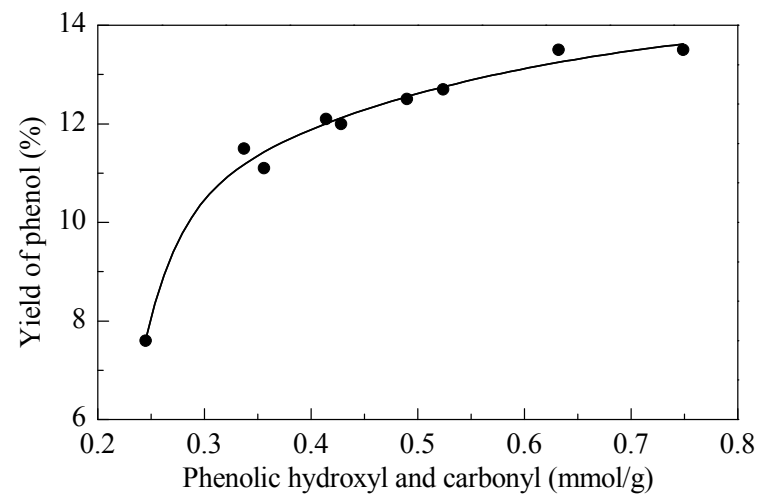

Fig. 8. Relationship between the yield of phenol and the sum of phenolic hydroxyl and carbonyl on the activated carbon after reaction.

On the basis of the above results, we can propose how the oxygen groups affected the catalytic performance. As discussed above, the oxygen groups of the activated carbon affected the hydroxylation of benzene by providing active sites, and affecting the $\mathrm{pH}$ of the system and amount of benzene adsorption. It was reported that hydroxyl radicals were produced during the activation of hydrogen peroxide by activated carbon [20,21], and quinone/phenolic groups act as electron transmitter $[22,43]$. Salicylic acid (SA, hydroxybenzoic acid) was used as a molecular probe to detect the hydroxyl radical [44]. When $22.5 \mathrm{mmol}$ SA was added into the system with WAC- $0.5 \mathrm{~N}, 6.2 \%$ phenol yield was obtained, which was only half of the result shown in Table 3 (12.5\%). Meanwhile, 2,3-dihydroxybenzoic acid and 2,5-dihydroxybenzoic were produced. The result indicated 
that the hydroxyl radical was involved in the hydroxylation of benzene. It can be proposed that the equilibrium between phenolic groups and quinone on the activated carbon activated $\mathrm{H}_{2} \mathrm{O}_{2}$ to form $\cdot \mathrm{OH}$, which reacted with benzene. This is illustrated in Fig. 9. The $o$-hydroquinone species was initially oxidized by $\mathrm{H}_{2} \mathrm{O}_{2}$ to $o$-semiquinone and subsequently quinone (o-quinone) while $\mathrm{H}_{2} \mathrm{O}_{2}$ got protons and electrons and formed $\cdot \mathrm{OH}$. Then, $\cdot \mathrm{OH}$ reacted with benzene producing the hydroxybenzene radical. Next, quinone was reduced by the hydroxybenzene radical to $o$-hydroquinone to produce phenol.

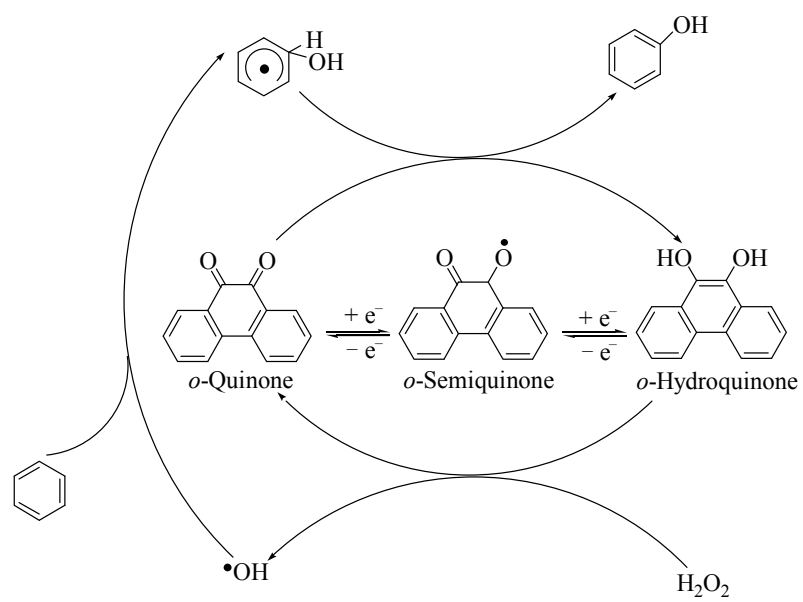

Fig. 9. Reaction pathway for the hydroxylation of benzene over activated carbon.

\subsection{Stability of the activated carbon catalyst}

To examine the recyclability of the activated carbon catalysts in the hydroxylation of benzene, WAC- $0.5 \mathrm{~N}$ and WAC- $0.5 \mathrm{~N}-8 \mathrm{H}$ were used for five cycles. As shown in Table 6 , the activity was kept almost constant after the first two runs. The results indicated that the catalyst was stable for the reaction.

Table 6 Reusability of WAC- $0.5 \mathrm{~N}$ and WAC- $0.5 \mathrm{~N}-8 \mathrm{H}$ for the hydroxylation of benzene

\begin{tabular}{cccccc}
\hline \multirow{2}{*}{ Run } & \multicolumn{2}{c}{ Yield of phenol (\%) } & & \multicolumn{2}{c}{ Selectivity for phenol (\%) } \\
\cline { 2 - 3 } \cline { 5 - 6 } & WAC-0.5N-8H & WAC-0.5N & & WAC-0.5N-8H & WAC-0.5N \\
\hline 1 & 13.5 & 12.5 & & 86.3 & 86.3 \\
2 & 12.9 & 12.7 & & 83.6 & 85.8 \\
3 & 12.2 & 10.5 & & 86.6 & 89.2 \\
4 & 11.9 & 10.9 & & 86.8 & 88.1 \\
5 & 11.7 & 10.8 & & 87.9 & 88.5 \\
\hline
\end{tabular}

\section{Conclusions}

Modified activated carbon showed good catalytic activity for the hydroxylation of benzene. Phenolic hydroxyl groups and quinone on the activated carbon were the active sites. The reaction between phenolic hydroxyl groups and quinone activated $\mathrm{H}_{2} \mathrm{O}_{2}$ to form $\cdot \mathrm{OH}$, which reacted with benzene to form phenol. The $\mathrm{pH}$ of the system is an important factor. Oxygen groups on the activated carbon have the roles in the hydroxylation of benzene that they provide active sites for the reaction, and affect the $\mathrm{pH}$ of the system and the amount of benzene adsorption.

\section{References}

1 Niwa S I, Eswaramoorthy M, Nair J, Raj A, Itoh N, Shoji H, Namba T, Mizukami F. Science, 2002, 295: 105

2 Zhang F M, Chen X, Zhuang J, Xiao Q, Zhong Y J, Zhu W D. Catal Sci Technol, 2011, 1: 1250

3 Yuranov I, Bulushev D A, Renken A, Kiwi-Minsker L. Appl Catal A, 2007, 319: 128

4 Tani M, Sakamoto T, Mita S, Sakaguchi S, Ishii Y. Angew Chem, Int Ed, 2005, 44: 2586

5 Dittmeyer R, Bortolotto L. Appl Catal A, 2011, 391: 311

6 陈佳琦, 高爽, 李军, 吕迎. 催化学报(Chen J Q, Gao Sh, Li J, Lv Y. Chin J Catal), 2011, 32: 1446

7 Chammingkwan P, Hoelderich W F, Mongkhonsi T, Kanchanawanichakul P. Appl Catal A, 2009, 352: 1

8 Abbo H S, Titinchi S J J. Appl Catal A, 2009, 356: 167

9 Zhang J, Tang Y, Li G Y, Hu C W. Appl Catal A, 2005, 278: 251

10 Song S Q, Yang H X, Rao R C, Liu H D, Zhang A M. Appl Catal A, 2010, 375: 265

11 Song S Q, Jiang S J, Rao R C, Yang H X, Zhang A M. Appl Catal A, 2011, 401: 215

12 Choi J S, Kim T H, Choo K Y, Sung J S, Saidutta M B, Ryu S O, Song S D, Ramachandra B, Rhee Y W. Appl Catal A, 2005, 290: 1

13 Zhong Y K, Li G Y, Zhu L F, Yan Y, Wu G, Hu C W. J Mol Catal A, 2007, 272: 169

14 Chen C H, Xu J Q, Jin M M, Li G Y, Hu C W. Chin J Chem Phys, 2011, 24: 358

15 Rodríguez-Reinoso F. Carbon, 1998, 36: 159

16 陈晨, 林性怡, 于政锡, 陈晓晖, 郑起, 魏可镁. 石油化工 (Chen Ch, Lin X Y, Yu Zh X, Chen X H, Zheng Q, Wei K M. Petrochem Technol), 2004, 33: 1024

17 Song W, Li Y, Guo X H, Li J, Huang X M, Shen W J. J Mol Catal A, 2010, 328: 53

18 Yu G X, Lu S X, Chen H, Zhu Z N. Carbon, 2005, 43: 2285

19 Pereira M F R, Órfão J J M, Figueiredo J L. Appl Catal A, 1999, 184: 153

20 Georgi A, Kopinke F D. Appl Catal B, 2005, 58: 9

21 Ono Y, Matsumura T, Kitajima N, Fukuzumi S I. J Phys Chem, 1977, 81: 1307

22 Donnet J B. Carbon, 1968, 6: 161

23 Boehm H P. Carbon, 1994, 32: 759

24 Takaoka M, Yokokawa H, Takeda N. Appl Catal B, 2007, 74 179

25 Guo B, Zhu L F, Hu X K, Zhang Q, Tong D M, Li G Y, Hu C W. Catal Sci Technol, 2011, 1: 1060 
26 Boehm H P. In: Eley D D, Herman P, Weisz P B eds. Advances in Catalysis. New York: Academic Press, 1966. 179

27 Goertzen S L, Thériault K D, Oickle A M, Tarasuk A C, Andreas H A. Carbon, 2010, 48: 1252

28 Oickle A M, Goertzen S L, Hopper K R, Abdalla Y O, Andreas H A. Carbon, 2010, 48: 3313

29 Boehm H P, Diehl E, Heck W. Proceedings of the 2nd London Carbon and Graphite Conference. London, UK, 1965. 369

30 Brunauer S, Deming L S, Deming W E, Teller E. J Am Chem Soc, 1940, 62: 1723

31 朱赛, 何欣雅, 赵亮, 李惠萍. 化学通报(Zhu S, He X Y, Zhao L, Li H P. Chemistry), 2010, 3: 284

32 Moreno-Castilla C, López-Ramón M V, Carrasco-Marín F. Carbon, 2000, 38: 1995

33 Zerda T W, Yuan X, Moore S M, Leon y Leon C A. Carbon, 1999, 37: 1999

34 Figueiredo J L, Pereira M F R, Freitas M M A, Órfão J J M. Carbon, 1999, 37: 1379

35 贾建国, 李闯, 朱春来, 肖春英, 徐东, 问欣, 梁长海. 炭素
技术(Jia J G, Li Ch, Zhu Ch L, Xiao Ch Y, Xu D, Yan X, Liang Ch H. Carbon Techniques), 2009, 28(6): 11

36 Zielke U, Hüttinger K J, Hoffman W P. Carbon, 1996, 34: 983

37 Moreno-Castilla C, Carrasco-Marín F, Mueden A. Carbon, 1997, 35: 1619

38 Larsen E C, Walton J H. J Phys Chem, 1940, 44: 70

39 León y León C A, Radovic L R. In: Thrower P A ed. Chemistry and Physics of Carbon. New York: Marcel Dekker, 1994. 213

40 Biniak S, Szymański G, Siedlewski J, Swiatkowski A. Carbon, 1997, 35: 1799

41 Serp P, Figueiredo J L. Carbon Materials for Catalysis. New Jersey: Wiley, 2009. 177

42 Wibowo N, Setyadhi L, Wibowo D, Setiawan J, Ismadji S. J Hazard Mater, 2007, 146: 237

43 Van der Zee F P, Bisschops I A E, Lettinga G, Field J A. Environ Sci Technol, 2003, 37: 402

44 Diez L, Livertoux M H, Stark A A, Wellman-Rousseau M, Leroy P. J Chromatogr B, 2001, 763: 185 